\title{
Torrential Floods in Malaysia: Assessing the Loss and Vulnerabilities in Three Kelantan Villages
}

\author{
Prof. Dr.A.H.M.Zehadul Karim¹ \\ Assoc. Prof. Dr. Hazizan Md. Noon² \\ Assoc Prof. Dr. Nurazzura Mohammad Diah ${ }^{3}$ \\ Dr. Nor Azlin Tajuddin 4 \\ Dr. Sohela Mustari ${ }^{5}$ \\ 1, 2, 3, 4 International Islamic University Malaysia. Dept. of Sociology and Anthropology. Gombak 53100, Kuala Lumpur. Malaysia \\ 5 Southeast University, Bangladesh. School of Business Studies. Banani 1213. Dhaka. Bangladesh
}

\section{Doi:10.5901/mjss.2016.v7n5p192}

\section{Abstract}

This research is an attempt to explore the socio-economic loss and vulnerabilities of the people in three villages of Kelantan State who have been considered as the worst victims of the calamity in December 2014 Flood in Malaysia. Three villages Kg.Laloh, Kg Manjor and Kg Manik Urai Lama were chosen purposively which later were surveyed most extensively to make the study totally enumerated in nature. As part of the qualitative study, the research conducted three FGDs and ten in-depth interviews. Findings of the study indicate that with a few exceptions, the great majority of the villagers regardless of their sociodemographic position, suffered badly from the floods in terms of losing their homes, food, pure drinking water and having no transport and carrier for immediate shiftment. In addition to these vulnerabilities, villagers having farming or/and farming related activities also endured badly as many of them lost their crops and animals during the flood. Based on the above, the research suggests that the government or policy planners consider building shelters in strategic locations of the villages immediately to protect the life of the people during the flood upsurge in the future and thus reduce their vulnerabilities. It is advisable that a community resilience and preparedness should be well articulated in advance with the involvement of the local people. There should be proper coordination in providing aid to the people during the flood so that all the victims receive them equally to mitigate their economic crises and sufferings.

Keywords: Floods of 2014, Malaysian Context, Assessing the loss, Vulnerabilities, Future Protection

\section{Introduction and Background of the Study}

Human beings normally go through a very solitary life which can suddenly be disrupted due to natural calamities and in these calamitous situations, people become vulnerable, helpless and shelterless which result in immense suffering and distress. Environmentalists and social scientists often conceptualize a holistic viewpoint of such natural disasters and accordingly, explore the indigenous mechanisms to cope with such critical situations. Often, researchers cannot ignore the societal experiences of natural disasters and thus consider both emic and etic viewpoints to solve the resultant problems. Among natural calamities, flooding causes great vulnerability to the affected people by destroying their livelihood options and properties, damaging bio-diversity and finally posing great threat to the lives of the affected people (see Dolan \& Walker 2006; Armah et al., 2010; Chan 2012; Karim 2014). To examine such impact of flooding in general and particularly in relation to the devastating floods in Malaysia in December 2014, we focus on the socio-economic vulnerabilities of the affected people in three villages in the state of Kelantan in Malaysia.

This research aims to ascertain first of all, the problems and difficulties that the residents had faced during the floods of 2014 and simultaneously explore the socio-economic vulnerabilities of the people by providing primary data based on intensive field work in three villages in Kelantan. The severe floods had displaced a huge number of people and caused sufferings for more than 250,000 people in 11 states of the country destroying people's properties worth RM560 million (Karim 2016). This is the worst form of flood which had inundated major areas of the country and it is said that people in these areas have not seen such disaster in the last 30 years. The floods caused enormous socio-ecological vulnerabilities for the people by creating problems and affecting their livelihood in fishing and tourism. It also affected 
other jobs, local businesses and investments. Simultaneously, it destroyed their agriculture such as rubber, palm oil, and livestock such as poultry. Prior to the disaster, most of the families in these villages survived by working as labourers in rubber and palm industries but they remained jobless for many days during and after the floods. Besides these, the villagers' social life was also immensely affected as they had scarcity of food and drinking water, loss of immediate shelter, shortage of relief as well as health care support during and after the catastrophe.

In recent years, floods occur in Malaysia quite frequently, yet the villagers do not have much experience in protecting themselves from such disasters and for that reason, it is quite likely they suffer quite a lot. Since the villagers were fully unprepared to face the flood of 2014, they panicked in witnessing the rising water levels. They did not store food nor did they arrange any other primary aid to meet the immediate needs. Furthermore, their miseries were compounded when relief and other support were delayed due to high levels of water. Their miseries continued even after the floods had subsided as they had very limited options to start life anew.

\section{A Brief Review of Literature}

Floods relating to large-scale riverine and coastal upsurges are very common and frequent throughout the world. It has been identified as the number one reason for loss of lives, damage of properties and degrading environmental problems which cause disruption to the normal way of life. Thus, flooding as a significant natural disaster creates malfunctioning of the society, having diverse and tremendous indirect implications on social life with massive vulnerabilities of the people. To overcome these vulnerabilities, victims often adopt many mechanisms, thus, making the society resilient and resettable. This part of the paper reviews a few such articles and books on flooding which seem to be suitable and relevant to the flooding situation in Malaysia.

Parker (2000) edited a book simply titled 'Flood' which compiles as many as forty articles on aspects of flood hazards as both natural and social phenomena underpinning the necessity of institutional and community involvement for proper resilience. This book contains articles discussing flood policy approaches and how a community is less affected by flood hazards depending on how they adapt and be resilient in their community life. Proverbs, Brebbia and PenningRowsell (2008) have edited another book entitled, 'Flood, Recovery, Innovation and Response' focusing on flood risk management strategies along with the rehabilitation and restoration of the normal way of life. Among the six sections of the book, articles covering coping strategies have been incorporated which provide us with significant policies for social and natural protections.

In their article, Lunt, Jones, Mulhern, Lezaks, and Jahn, (2016) assess climate risks and vulnerabilities on human life. They proclaim that climate risks like floods and droughts cause a threat on the global food system. These risks also impacts global economic sector, governments' steadiness and health situation. Khalil (2016) in his proceeding paper states that a developing country must enjoin the link with the marginal communities with that of the majorities but many countries like Pakistan have failed to bring the marginal people into the mainstream. To exemplify, it can be stated here that the marginal communities of Pakistan are suffering tremendously due to climate change effects. Farming is dependent on these marginal communities who suffer badly because of floods and droughts as their agricultural activities, fish farming and other related livelihoods are destroyed. This paper demonstrates the indigenous knowledge which helps the marginal people to reduce their vulnerabilities and to save their lives. Finally, the paper suggests arranged dialogues between different intellectuals and stakeholders to solve the problems. The above views can also be shared by Malaysian authorities in relation to developing resiliencies at the community level as they expect to reduce sufferings for the people during and after floods (Government of Malaysia 2007; Weng 1995).

\section{Significance and Rationale for this Research}

There are a number of environmentalists and social scientists (e.g. Adger, Hughes, Folke, Carpenter \& Rockstrom, 2005; Posthumus, Morris, Hess, Neville, Phillips \& Baylis, 2009; Armah, Yawson, Yengoh, Odoi \& Afrifa, 2010; Karim, 2014; Mustari 2015; Buckland, \& Rahman, 1999; Grothmann, \& Reusswig, 2006) who have carried out many important research on the vulnerabilities of the coastal people during floods and other natural disasters, showing their implications on human life and living. Heavy rain and severe floodings in December 2014 caused Malaysia to become victim of such occurrence which created enormous vulnerabilities to the people in the country. This research conceptualizes such socioeconomic vulnerabilities due to this severe flooding and thus identifies the stress that emerged within the people during and after the calamity. The research specifically locates the socio-economic problems and constraints to ascertain as to how these people responded to such catastrophes. From this perspective, this empirical research explores and uncovers the indigenous resilient strategies that the local people had adopted to face such problems which are epitomized in this 
research in an analytic-descriptive presentation. Based on this, a community resilient strategy is adopted in this research which will be a new dimension to conceptualize flooding in Malaysia. An exploration of these resilient issues relating to the problems of flood-affected people is essential as this dimension of floods has remained unexplored until now. The paucity of studies and a gap of such dimension have remained important rationale for this research. Thus, it seems that research on socio-economic vulnerability is academically significant and pragmatically relevant as well.

\section{Methodology and Data Sources}

Three villages in Kelantan, named Kampung Laloh, Kampung Manjor and Kampung Manik Urai Lama were purposively chosen to collect the required data. This research is the triangulation of qualitative technique of employing researchers' own participation in the field for observations and having informal interviews with the villagers. As part of the qualitative study, the research conducted 3 FGDs in these villages, generating one each at every village. A total of 10 in-depth interviews were conducted in all three villages with people from different categories having profound knowledge and understanding about the occurrence. To supplement it further and to make the study holistic and totally enumerative in nature, the research conducted a survey on 300 households, taking 100 each from these three villages. Apart from the total enumeration technique of conducting the survey the research additionally employed the convenient sampling procedure for informal interviews.

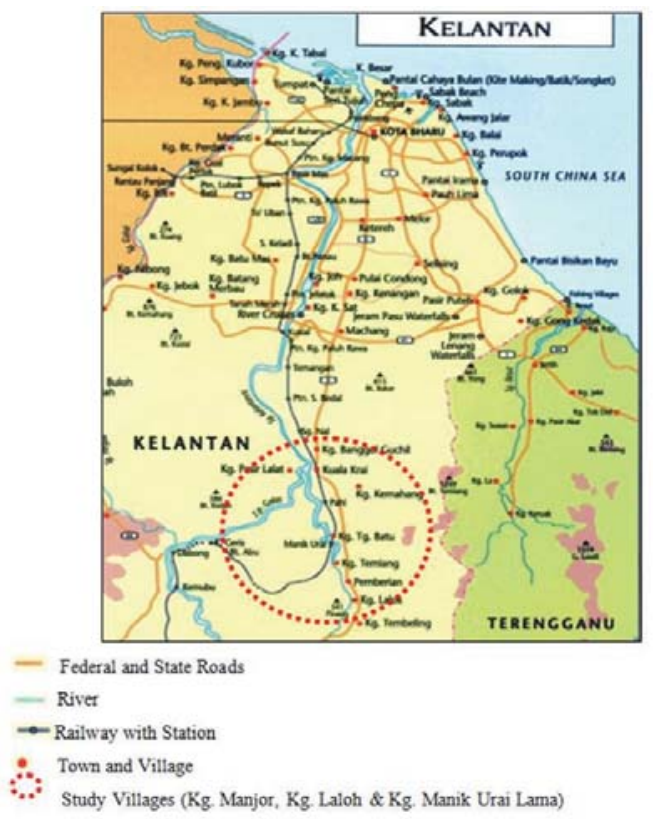

Figure 1: Map of Kelantan showing the three study villages

Source: http://mapsof.net/malaysia/malaysia-kelantan-map

\section{Ecological Setting of the Villages and Socio-Demographic Information of the Respondents:}

Being located in the same physiographic region, the flooding problems encountered by Kelantan villagers are very common and seem to be almost similar for all. Although it is expected that their economic activities would centre around agriculture, in reality, most of the villagers are rubber tappers and general workers seeking earnings from commercially planted rubber trees. It is therefore quite likely that the villagers are involved in many other occupations creating the diversification which is essential for their subsistence. It is very much related to the economic necessities that force them to carry out their activities to maintain their families. The predominance of non-agricultural occupations in the selected villages in Kelantan may also be explained by the fact that each family has numerous means of generating income. 
Table 1. Some Basic Socio-Demographic Indicators about the Villagers

\begin{tabular}{|c|c|c|c|}
\hline Respondents' Age & $\begin{array}{c}\text { Kg.Laloh } N=100 \\
\text { f }(\%)\end{array}$ & $\begin{array}{c}\text { Kg Manjor } N=100 \\
f(\%)\end{array}$ & $\begin{array}{c}\text { Kg Manik Urai Lama }=100 \\
f \quad(\%)\end{array}$ \\
\hline Young (up to 35 years old) & $18(18 \%)$ & $19(19 \%)$ & $13(13 \%)$ \\
\hline Middle aged ( 36 to 50 years) & $32(32 \%)$ & $35(35 \%)$ & $35(35 \%)$ \\
\hline Old persons (51 and above) & $50(50 \%)$ & $46(46 \%)$ & $52(52 \%)$ \\
\hline Education & $\mathrm{N}=100$ & $\mathrm{~N}=51$ & $\mathrm{~N}=100$ \\
\hline No formal education & $22(22 \%)$ & --- & $35(35 \%)$ \\
\hline primary level (up to year 5) & $18(18 \%)$ & $23(45.19 \%)$ & $34(34 \%)$ \\
\hline SPM or secondary level & $46(46 \%)$ & $28(54.90 \%)$ & $29(29 \%)$ \\
\hline Diploma & $8(8 \%)$ & --- & $2(2 \%)$ \\
\hline Graduate & $6(6 \%)$ & --- & --- \\
\hline \multicolumn{4}{|c|}{ Occupational Groupings Based on Principal Work ${ }^{1}$} \\
\hline Administration & $6(6 \%)$ & $3(3 \%)$ & $4(4 \%)$ \\
\hline Baby Sitter ${ }^{2}$ & $4(4 \%)$ & $2(2 \%)$ & $6(6 \%)$ \\
\hline Clerk & $3(3 \%)$ & $2(2 \%)$ & $5(5 \%)$ \\
\hline Driver & $4(4 \%) 1$ & $5(5 \%)$ & $7(7 \%)$ \\
\hline Entrepreneur & $6(6 \%)$ & $5(5 \%)$ & $9(9 \%)$ \\
\hline Guard & $7(7 \%)$ & --- & $6(6 \%)$ \\
\hline Housewife & $6(6 \%)$ & $11(11 \%)$ & $23(23 \%)$ \\
\hline Self-employed ${ }^{3}$ & $23(23 \%)$ & $16(16 \%)$ & $12(12 \%)$ \\
\hline Labour $^{4}$ & $28(28 \%)$ & $41(41 \%)$ & $18(18 \%)$ \\
\hline Not working & $9(9 \%)$ & $14(14 \%)$ & $8(8 \%)$ \\
\hline Retirees & $4(4 \%)$ & $1(1 \%)$ & $2(2 \%)$ \\
\hline \multicolumn{4}{|l|}{ Income } \\
\hline No Income & $22(22 \%)$ & $33(33 \%)$ & $35(35 \%)$ \\
\hline Low income group (up to RM 1999) & $68(68 \%)$ & $64(64 \%)$ & $61(61 \%)$ \\
\hline Medium income (RM2000-3999) & $8(8 \%)$ & $3(3 \%)$ & $2(2 \%)$ \\
\hline Higher income (RM4000 and above) & $2(2 \%)$ & --- & $2(2 \%)$ \\
\hline
\end{tabular}

${ }^{1}$ Classifying the occupations into principal and subsidiary groups does not seem to be significant for economic analysis in this research as it is not very reflective of their real earnings. In the investigation, it is also very difficult to properly ascertain the extent of their income from each occupation. Almost all of the villagers are directly or indirectly involved in rubber tapping and other agricultural works which however, are seasonal. For that reason, apart from farming, fishing and rubber tapping, they have chosen one more occupation which can be regarded as their principal work as they derive a regular fixed income from this principal work which is justifiable.

${ }^{2}$ These are the female headed households where the women often work as baby sitters at their homes.

${ }^{3}$ Self-employment means that they independently run some petty businesses of their own.

${ }^{4}$ These are the hired labourers who work in both agricultural and non-agricultural activities.

As their economic activities are very much dependent on the current market value of raw products, their monthly income for that reason, fluctuates depending on the market mechanisms. This unpredictability of their economic transaction is a cause of their relative poverty and low standard of living. Those with low income and poor education suffer from acute chronic diseases such as asthma, gout, high blood pressure, diabetes, and others. Most of the respondents admitted that they do not send their children for higher education which clearly indicates that they have little awareness about education which effectually cause them to acquire lesser knowledge about vulnerability issues.

\section{Results and Discussions}

\subsection{Assessing the Loss of Properties and Valuables:}

Apart from the above specific problems, we have estimated people's total loss of properties and valuables, calculated in ringgit as shown in Table 2. A calculation of the monetary loss estimated in the three villages comes to RM12,643,927 of which more than $70 \%$ amounting to RM8,856,290 in total, is the loss which came from the destruction of houses. The remaining loss of $30 \%$ covers other items like furniture, transport, land and other properties. Looking at the individual villages, the pattern of loss is almost similar in all three, though the proportion of loss is slightly larger in the case of Manik Urai Lama as the village is located close to the banks of the river. 
Table 2: Loss of Properties and Valuables during the 2014 Floods

\begin{tabular}{|c|c|c|c|c|c|c|c|c|c|}
\hline & \multicolumn{3}{|c|}{ KG*. LALOH } & \multicolumn{3}{|c|}{ KG. MANJOR } & \multicolumn{3}{|c|}{ KG. MANIK URAI LAMA } \\
\hline Valuable items lost during the flood & Respondent & $\begin{array}{l}\text { Total } \\
\text { Loss }\end{array}$ & $\begin{array}{c}\text { Average } \\
\text { Loss }\end{array}$ & Respondent & $\begin{array}{l}\text { Total } \\
\text { Loss } \\
\end{array}$ & $\begin{array}{c}\begin{array}{c}\text { Average } \\
\text { Loss }\end{array} \\
\end{array}$ & Respondent & $\begin{array}{l}\text { Total } \\
\text { Loss } \\
\end{array}$ & $\begin{array}{c}\text { Average } \\
\text { Loss }\end{array}$ \\
\hline House & 67 & $\begin{array}{c}\text { RM } \\
1193790 \\
\end{array}$ & $\begin{array}{c}\mathrm{RM} \\
17817 \\
\end{array}$ & 77 & \begin{tabular}{|c|} 
RM \\
1278500 \\
\end{tabular} & \begin{tabular}{|c|} 
RM \\
16603 \\
\end{tabular} & 89 & \begin{tabular}{|c|} 
RM \\
6384000 \\
\end{tabular} & \begin{tabular}{|c|} 
RM \\
71730 \\
\end{tabular} \\
\hline Furniture & 73 & $\begin{array}{c}\mathrm{RM} \\
483100 \\
\end{array}$ & $\begin{array}{c}\mathrm{RM} \\
6618 \\
\end{array}$ & 68 & $\begin{array}{c}\text { RM } \\
669300 \\
\end{array}$ & $\begin{array}{c}\mathrm{RM} \\
9842 \\
\end{array}$ & $\begin{array}{l}\text { RM } \\
89 \\
\end{array}$ & \begin{tabular}{|c|} 
RM \\
857000 \\
\end{tabular} & $\begin{array}{c}\text { RM } \\
9629 \\
\end{array}$ \\
\hline Transportation & 48 & $\begin{array}{c}\mathrm{RM} \\
199750 \\
\end{array}$ & $\begin{array}{c}\mathrm{RM} \\
4161 \\
\end{array}$ & 62 & \begin{tabular}{|c|}
$\mathrm{RM}$ \\
611607 \\
\end{tabular} & $\begin{array}{c}\mathrm{RM} \\
9864 \\
\end{array}$ & 75 & \begin{tabular}{|c|} 
RM \\
519800 \\
\end{tabular} & $\begin{array}{c}\text { RM } \\
6930\end{array}$ \\
\hline Cultivable land and Homestead land & 6 & $\begin{array}{c}\text { RM } \\
21900 \\
\end{array}$ & $\begin{array}{c}\text { RM } \\
7299 \\
\end{array}$ & 3 & $\begin{array}{c}\text { RM } \\
7200 \\
\end{array}$ & $\begin{array}{c}\text { RM } \\
2400 \\
\end{array}$ & 12 & $\begin{array}{c}\mathrm{RM} \\
14000\end{array}$ & $\begin{array}{c}\text { RM } \\
1166 \\
\end{array}$ \\
\hline Other properties & & $\begin{array}{c}\mathrm{RM} \\
113710 \\
\end{array}$ & $\begin{array}{c}\mathrm{RM} \\
58140 \\
\end{array}$ & & \begin{tabular}{|c|}
$\mathrm{RM}$ \\
121670 \\
\end{tabular} & $\begin{array}{c}\text { RM } \\
34817 \\
\end{array}$ & & \begin{tabular}{|c|} 
RM \\
160100 \\
\end{tabular} & \begin{tabular}{|c|} 
RM \\
16592 \\
\end{tabular} \\
\hline TOTAL & & \begin{tabular}{|c|} 
RM \\
2012250 \\
\end{tabular} & & & \begin{tabular}{|c|}
$\mathrm{RM}$ \\
2688277 \\
\end{tabular} & & & \begin{tabular}{|c|} 
RM \\
7943400 \\
\end{tabular} & \\
\hline
\end{tabular}

$\mathrm{KG}^{*}=\mathrm{KG}$ is the short abbreviation of the word Kampung which means village.

\section{Specific Problems and Vulnerabilities Encountered by the Villagers During and After Flood}

While the villagers were asked about the problems and vulnerabilities they encountered during the flood, a number of issues emerged which have been analysed below:

(i) Problems of Evacuation during the Flood: The villagers were asked to describe the most severe problems they had encountered during the flood; an overwhelming majority of the respondents mentioned that they had difficulties in evacuating and getting rid of the water as most of the transportation belonging to them were damaged or not traceable. Moreover, it became difficult to arrange transportation for immediate movement at the time of crises. Many of the villagers also mentioned that they were at a lost at that time and were anxious to save their lives.

(ii) Housing and Settlement Problems: After the December Flood of 2014, the majority of the villagers were still in the recovery process as during the first and last phases of our fieldwork, we found a number of people who were still living in damaged houses or were still trying to repair their houses. In May and June of 2015, a few months after the disaster, at the entrance of Kampung Manik Urai Lama, the researchers found at least six families who were still living in some temporary shelters. The shadow-lines of water levels of many houses were still noticeable indicating the depth of the water level and the havoc of danger. In the early phase of our fieldwork, many houses were seen without windows, doors, and some even without roofs; but in the second phase of our fieldwork, the situation had improved to some extent, although there were many villagers still struggling with repairing their half-done house-work. It may be noted that a few villagers being economically better-off had been able to rebuild their houses instantly but slightly with modern infrastructure. Moreover, because of their social positions some villagers were able to establish good networking with others which helped them to benefit economically to overcome their housing problems. Others claimed that although they received financial support from various sources, the amount of money was not sufficient to rebuild their houses. However, during the later part of our fieldwork conducted in February through March, 2016, we found that the government has built permanent accommodations on higher grounds for the poor families who had lost their houses during the flood thus making them happy and safe. We visited Kg.Manik Urai Lama where the houses were waiting for completion and handing over of the keys to the distressed victims of the flood.

(iii) Lack of Shelter: In narrating the problems and vulnerabilities faced by the people during the flood, it is reported that none from the three villages had proper and immediate flood shelters; many of them had to take shelter in nearby schools. A few of the villagers even climbed up the hills for safety. When we visited some of the schools after the flood subsided we measured the water level which clearly showed that the high flood levels (around 25 feet or approximately reaching the second floor of the schools) meant that schools were no longer appropriate shelters nor were they sufficient to accommodate big numbers of displaced persons during the flood. This will force many to relocate to higher grounds but travelling would not be easy as most of them did not have boats. Although a few boats were given by the government and non-government organisations, they were insufficient and did not satisfy many people. Families with old people, women, and children suffered a lot when relocating to the higher grounds which did not offer proper facilities for shelter so people remained 
isolated and did not receive any food or water until the water level had gone down. For that reason, these victims remained in the mountains without food and water for two days consecutively and had to wear the same wet clothes for these days as they did not have any alternatives. Sanitation was poor and observing religious rituals became very difficult.

(iv) Flood Aid: The villagers claimed that floods in Malaysia are now becoming very common as the people are experiencing it almost every year in December; the severity of the flood of 2014 was massive. Many became jobless and homeless being dependents on aid and donations from government and non-government sources. But they were not satisfied with the aid management procedures as during the flood many did not receive food, water, and other basic necessities. Those who had toddlers and infants agonised over the provision of baby food. Moreover, there was no coordination among various donors as many of the villagers complained that some of them received the same things repeatedly while they did not receive other necessities. Apart from that, villagers who were at the central and communicable points of the villages received aid more than the villagers who were in remote parts. In the case of Kampung Manjor located at the borders of Kelantan and Kedah, the villagers did not receive adequate aid from either state (see Karim et. al. 2016)

However, the villagers indicated their gratitude to non-government organisations. Although both government and non-government donors were not prepared in distributing aid, non-government donors tried their best to supply the required necessities from food to housing infrastructure. By staying with the villagers a couple of weeks from 8 am to $5 \mathrm{pm}$, we observed that many non-government organisations from Korea and China donated housing infrastructure to the flood victims. At the same time, some donated housing equipment without mentioning their names. In the same way some universities like UPSI provided financial help to rebuild houses. However, the villagers criticised the duplication of aid given to the same persons because of their active social networking which reflects the requirement of integration in distributing aid (see Karim et al. 2016).

(v) Land and Agriculture: Economic activities in rural areas are fully dependent on the type of land resources available in the village and it is probably the most important indicator in deciding their economic profession; that is what happened in the case of our villages. After informal discussions with a number of villagers, it was found that most villagers work as labourers in agricultural farms. They work as rubber tappers on plantations owned by outside investors. Most have no agricultural farm of their own, with only a few of the villagers owning private land for cultivation. They use these lands to secure their livelihoods with small and home-based private farms. They cultivate bananas, mangoes, guavas, and other fruits for sale. These farms were devastated during the floods, robbing people of their incomes. Since the villagers do not go for intensive crop-based agriculture, many of them for that reason do not possess any heavy cultivation equipment. Very few villagers have farm animals. Villagers with cattle and poultry suffered as they tried to bring these animals to the hills but many died due to high flood levels. Having boats could have changed this outcome.

(vi) Trees and Bio-diversity: All three villages were surrounded by trees which are sources of rich bio-diversity and also simultaneously, used to protect the river from erosion. The Kelantan River which caused this recent flooding had big trees uprooted along the river banks causing massive destruction to the environment. It is reported that these trees had fallen because saline water coming from the sea mixed with the river water during the flood, causing these trees and greenery to die.

With participant observation, the researchers found that forests beside the river died where more than thousands of trees were affected. Some villagers claimed that they tried to replace the trees but it was not possible as saline water destroyed the field productivity. Though the trees and lands are unproductive, but after visiting Kelantan River a few months later, an opposite scenario was noticed by the researchers. The river is lack of water by the mid of 2015 and in some parts the lands beside the river seems almost like desert which are absolutely caught by drought (see Karim et al. 2016). Many of the villagers claimed that it is happening by rotation that sometimes they are attacked by flood and in some other time they are attacked by drought. Villagers are expecting a permanent solution of this game of nature. Apart from trees and greenery, the villagers shared their feelings for their pet also. Many of them screamed as they were needed to leave their pets in the flood water to save their own life first.

\section{Conclusion}

It was found that all the villagers during the flood had severely suffered from not having suitable shelter which caused them to move up to the highlands and mountains. Lack of proper carrier for shiftment caused massive sufferings for the seniors, women and children. Informal discussions with the villagers also indicate that enormous mismanagement had occurred in the distribution of aid during and after the floods. According to the villagers, those who live in remote parts of 
the villages did not get proper food and drinking water from the donors. Since the government or any other organizations did not immediately build any shelter for the flood victims, the villagers suffered from sanitation problems which affected their privacy. The villagers also mentioned their lack of security as they had to stay with wild animals and snakes roaming in the area. In addition to these vulnerabilities, villagers having farming or farming-related activities also endured badly as many of them lost their crops and animals during those floods. With few exceptions, the observations reflect that all the villagers, regardless of their socio-demographic position, suffered badly from the floods in terms of losing their shelter, lack of food and pure drinking water and also in having access to carriers for shiftment.

During our first phase of the fieldwork in July 2015, we found that many villagers were living inside tents and many others had been placed in poor housing conditions; however, some economically well-off persons had been able to rebuild their houses with modern bricks and sands right after the flood water ebbed away. Field data show that there was significant level of satisfaction with non-governmental organizations as many of the victims were getting financial and non-financial aid from them in rebuilding their houses and replacing other necessities in their lives. In addition, villagers who were dependent on home-based and commercial farms had suffered due to lack of financial investment and water salinity which occurred because of the high water levels. Observations justified the claim of the villagers who mentioned that a huge number of trees had fallen throughout the villages causing natural impact on their biodiversity. The common villagers who work in various rubber plantations had shown their dissatisfaction by stating that the recovery from the floods was absolutely impossible with the minimum amount of salary they were receiving from their work.

\section{Recommendations for Future Protections}

(a) Based on the above discussion, it is suggested that the government or policy planners consider building shelter houses in strategic locations immediately to protect the life of the villagers during flood upsurge in the future and thus reduce their vulnerabilities. (b) Since the people usually are unaware and remain unprepared about the calamities and since flood upsurge may occur all of a sudden, it is advisable that a community resilience and a preparedness programme should be articulated well ahead of time, with direct involvement of the local people. (c) Adequate relief, food supply, pure drinking water and sheltering services have to be made available instantly during and after the flood. At the same time, there should be some proper coordination in providing aid to the people during the flood so that all the victims receive them equally to mitigate their economic crises and sufferings. (d) As the floods occur at the village level, community level integrated initiatives should be planned to bring resiliency in after the flood.

\section{Acknowledgement}

The research reported here is funded by the Ministry of Higher Education, Government of Malaysia in the name of 'FRGS project' which is channeled and monitored by the Research Management Centre (RMC) of IIUM, for which the researchers are very much grateful. Dr. Sohela Mustari, a former PhD fellow of Professor Zehadul Karim has remained attached in different phases of the research. As a principal researcher, Dr.A.H.M.Zehadul Karim expresses his sincere gratitude to Dr. Sohela for her valuable contributions in every phase of the project.

\section{References}

Armah, F. A., Yawson, D. O., Yengoh, G. T., Odoi, J. O., \& Afrifa, E. K. (2010). Impact of floods on livelihoods and vulnerability of natural resource dependent communities in Northern Ghana. Water, 2(2), 120-139.

Buckland, J., \& Rahman, M. (1999). Community-based disaster management during the 1997 Red River Flood in Canada. Disasters, 23(2), 174-191.

Chan, N W. (2012). 'Impacts of Disasters and Disasters Risk management in Malaysia: The Case of Floods' in Swanda, Y and S. Oum (eds), Economic and Welfare Impacts of Disasters in East Asia and Policy Responses. ERIA Research Project Report 2011-8. Jakarta: ERIA. pp. 503-55.

Dolan, A.H.\& Walker, I.J. (2006). Understanding Vulnerability of coastal communities to climate change related risks. Journal of Coastal Research, 1316-1323.

Grothmann, T., \& Reusswig, F. (2006). People at risk of flooding: why some residents take precautionary action while others do not. Natural hazards, 38(1-2), 101-120.

Government of Malaysia (2007). Flood and Drought Management in Malaysia. Kuala Lumpur: Ministry of Natural Resources \& Environment.

Karim, A.H.M.Z (2014). "Flood and Riverbank Erosion Displacees: Their Indigenous Survival Strategies in Two Coastal Villages in 
Bangladesh". Asian Social Science (Canada). Vol 10, No.4. February.pp-16-26.

Karim, A.H.M.Z., Noon, M.H.; Noor, M.A; Nurazzura M. D.; \& Nor Azlin T; Dr. Sohela Mustari, S\& Sarker, M. S.I., (2016). Problems and Sufferings of the Flood-Affected People in Malaysia: A Study of Three Villages in Kelantan. A paper submitted for publication. South Asian Anthropologist Vol 15, No.2 December.

Karim, M.F., \& Mimura, N (2008) Impacts of Climate Change and Sea-level rise on cyclone storm surge floods in Bangladesh. Global Environmental Change, 18 (3). Pp490-500.

Khalil, S. (2016). Impacts of climate change on marginalized communities, tourism and their sustainable livelihood in a developing economy. WIT Transactions on Ecology and the Environment, 201, 91-101.

Lunt, T., Jones, A. W., Mulhern, W. S., Lezaks, D. P., \& Jahn, M. M. (2016). Vulnerabilities to agricultural production shocks: An extreme, plausible scenario for assessment of risk for the insurance sector. Climate Risk Management.

Messner, F., \& Meyer, V. (2006). Flood damage, vulnerability and risk perception-challenges for flood damage research (pp. 149-167). The Netherlands: Springer.

Mustari, Sohela (2015). Vulnarabilities and Resiliency of the Coastal Peopl;e of Bangladesh: A Sociological Study of Sathkhira Coastal areas. Unpublished PhD thesis. Department of Sociology and Anthropology, IIUM. Malaysia.

Parker, D.J (ed.) (2000). Flood Vol.1. London and New York: Routledge.

Posthumus, H., Morris, J., Hess, T. M., Neville, D., Phillips, E., \& Baylis, A. (2009). Impacts of the summer 2007 floods on agriculture in England. Journal of Flood Risk Management, 2(3), 182-189.

Proverbs, D., Brebbia C.A., \& Penning-Roswell E. (eds.), (2008). Flood Recovery, Innovation and Response. Southamton: WIT Press.

Weng Chan, N. (1995). Flood disaster management in Malaysia: an evaluation of the effectiveness of government resettlement schemes. Disaster Prevention and Management: An International Journal, 4(4), 22-29.

\section{Appendix 1}

\section{Socio-Economic Vulnerabilities of Flood Affected People in Malaysia: Some Suggestive Strategies to Reduce Sufferings QUESTIONNAIRE}

\section{Locality Identification:}

Name of the Village:

Name of the Mukim:

Respondent's Name: (Usually Head of the Household)

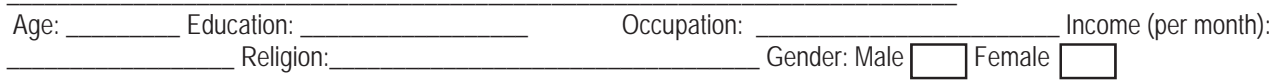

1. Details about family members (for purpose of total enumeration):

\begin{tabular}{|c|l|l|l|l|l|l|l|l|}
\hline & Name of person & Relationship with Head of Household & Age & Sex & Education & Occupation & Monthly Income \\
\hline 1. & & & & & & & \\
\hline 2. & & & & & & & \\
\hline 3. & & & & & & & & \\
\hline 4. & & & & & & & & \\
\hline 5. & & & & & & & & \\
\hline 6. & & & & & & & \\
\hline 7. & & & & & & \\
\hline
\end{tabular}

2. What kind of housing condition do you have at this time?

\begin{tabular}{|l|l|l|l|l|}
\hline \multirow{2}{*}{ Type of Houses } & & \multicolumn{3}{|c|}{ Financed by } \\
\cline { 3 - 5 } & Quality of the Houses & Self & Bank/ Bank Loan & Other Sources \\
\hline Temporary structure & Made of wood and bamboo & & & \\
\hline Permanent structure & Made of brick and concrete & & & \\
\hline
\end{tabular}

3. What kind of properties do you have?

\begin{tabular}{|l|l|l|}
\hline Property type & Amount of property holding (in acre) & Valuations (in ringgit) \\
\hline Cultivable land & & \\
\hline Land for homestead & & \\
\hline Unused land & & \\
\hline Land rented from others & & \\
\hline Cattle & & \\
\hline Poultry & & \\
\hline Trees & & \\
\hline Modern equipment for agriculture & & \\
\hline
\end{tabular}


4. Did you face any flood or/and disaster in your life in your village before 2014 ?

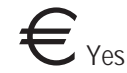

No

5. If the answer is yes, provide us with the specific time and history as below:

\begin{tabular}{|l|l|}
\hline Type of disaster & \multicolumn{1}{|c|}{ Year and month } \\
\hline Floods & \\
\hline Sea level rise & \\
\hline River-bank erosion & \\
\hline Land erosion & \\
\hline Drought & \\
\hline Water level down & \\
\hline
\end{tabular}

6. Have you lost any property during the last flood of 2014 ?

\begin{tabular}{|l|c|c|l|}
\hline \multirow{2}{*}{ Name of property } & \multicolumn{2}{|c|}{ Lost (please tick) } & \multirow{2}{*}{ Monetary value of the lost property (in Ringgit) } \\
\cline { 2 - 3 } & Yes & No & \multirow{2}{*}{} \\
\hline Arable Land & & & \\
\hline House & & & \\
\hline Animals /Cattle /Poultry & & & \\
\hline Trees & & & \\
\hline Crops & & & \\
\hline Fishing net & & & \\
\hline Fishing boat & & & \\
\hline Cultivated fish & & & \\
\hline
\end{tabular}

7. Have you faced any types of difficulties due to the severe flood in 2014?

\begin{tabular}{|l|l|l|}
\hline \multirow{2}{*}{ Types of difficulties } & \multicolumn{2}{|c|}{ Difficulties (please tick) } \\
\cline { 2 - 3 } & & Yes \\
\hline Degradation of land quality & & \\
\hline Drinking water scarcity & & \\
\hline Land pattern change & & \\
\hline Change and dislocation in family structure & & \\
\hline Change in labor force pattern & & \\
\hline Change in food habit & & \\
\hline Remain unemployed & & \\
\hline Problems in children's Schooling & & \\
\hline
\end{tabular}

8. During the last $2014-2015$ flood, what kind of problems did you face on the following basic needs?

\begin{tabular}{|l|c|c|}
\hline \multirow{2}{*}{ Basic needs } & \multicolumn{2}{|c|}{ Problems Faced (please tick) } \\
\cline { 2 - 3 } & \multicolumn{1}{|c|}{ Yes } \\
\hline Food & & \\
\hline Clothing & & \\
\hline Shelter & & \\
\hline Education & & \\
\hline Medicine & & \\
\hline
\end{tabular}

9. What specific health problems did you face during the 2014-2015?

\begin{tabular}{|l|l|l|}
\hline \multirow{2}{*}{ Diseases } & \multicolumn{2}{|c|}{ Please tick $(\sqrt{ })$} \\
\cline { 2 - 3 } & Yes & No \\
\hline Diarrhoea & & \\
Fever & & \\
Vomiting and nausea & & \\
\hline Skin disease & & \\
\hline Any other diseases, please mention specifically & & \\
\hline
\end{tabular}


10. How did you solve those health-related problems?

\begin{tabular}{|l|l|l|l|l|}
\hline & On my own & Taking medicine from village quack & Going to the clinic/hospital & It was cured automatically \\
\hline Skin disease & & & & \\
\hline Please tick $(\sqrt{ })$ & & & & \\
Fever & & & & \\
Malaria & & & & \\
Typhoid & & & & \\
\hline Vomiting and nausea & & & & \\
\hline Diarrhoea & & & & \\
\hline Any other Diseases & & & & \\
\hline
\end{tabular}

11. What did you do to cope with the economic crisis during the flood of 2014 ?

\begin{tabular}{|l|c|c|}
\hline Type of activities to face the economic crisis & \multicolumn{2}{|c|}{ Activities (Please tick) } \\
\cline { 2 - 3 } & Yes & No \\
\hline Planting new crops after the flood & & \\
\hline Migrating to other areas & & \\
\hline Selling domestic valuables & & \\
\hline Taking loan from relatives & & \\
\hline Taking loan from govt/non-govt sources & & \\
\hline Changing of traditional work and finding new types of employment activities. & \\
\hline Selling tangible Property (please specify) & & \\
\hline Selling Intangible Property(please specify) & & \\
\hline
\end{tabular}

12. What kind of necessary social, economic and psychological support did you expect during the flood of 2014-2015?

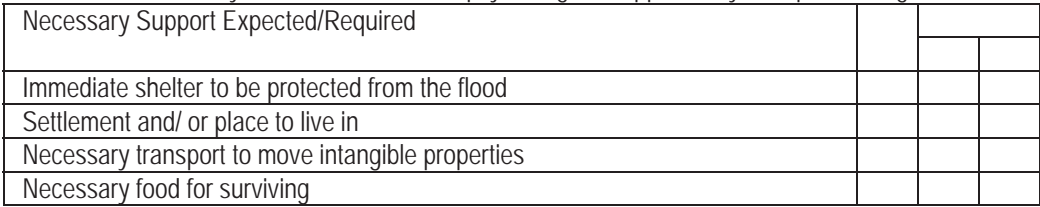

13. Please tell us about the social and financial support that you received during the t flood of 2014-2015.

\begin{tabular}{|l|l|l|l|}
\hline Help provider & Please tick & Monetary or others) & Monetary value of the help (In Ringgit) \\
\hline Government & & & \\
\hline Non-government organizations & & & \\
\hline Local rich people & & & \\
\hline Relatives & & & \\
\hline Friends & & & \\
\hline Outsiders & & & \\
\hline Local People & & & \\
\hline
\end{tabular}

14. Please tell us about the acute problems that you faced during the flood of 2014-2015.

(a)

(b)

(c)

(d)

(e)

15. Based on your experience, what strategies do you suggest for the community in facing such severe flood?

(a)

(b)

(c)

(d)

(e) 